\title{
Counteracting urban climate change: adaptation measures and their effect on thermal comfort
}

\author{
Nicole Müller • Wilhelm Kuttler • Andreas-Bent Barlag
}

Received: 6 December 2012 / Accepted: 24 March 2013 / Published online: 17 April 2013

(C) The Author(s) 2013. This article is published with open access at Springerlink.com

\begin{abstract}
Cities represent thermal load areas compared with their surrounding environments. Due to climate change, summer heat events will increase. Therefore, mitigation and adaptation are needed. In this study, meteorological measurements in various local climate zones were performed to demonstrate the influence of evaporation surfaces and other factors on thermal comfort, as determined by the physiologically equivalent temperature (PET). Furthermore, a quantification of the thermal effects of several adaptation measures and varying meteorological parameters was made using model simulations (ENVI-met) in an inner-city neighborhood (Oberhausen, Germany). The results show that the most effective adaptation measure was increased wind speed (maximal $15 \mathrm{~K}$ PET reduction). Moreover, vegetation areas show greater PET reductions by the combination of shading and evapotranspiration than water surfaces. The creation of park areas with sufficient water supply and tall, isolated, shade-providing trees that allow for adequate ventilation can be recommended for planning.
\end{abstract}

\section{Introduction}

In previous decades, global climate change has manifested itself most obviously in increases in near-surface air temperatures, and this trend is expected to continue (IPCC 2007). Even in cities in the Ruhr metropolitan area of Germany $(>5$ million inhabitants; RVR 2011), which already exhibit significant weather-dependent urban heat islands (UHIs) relative to their surrounding environments, additional thermal stress for humans is expected in association with the projected increases

\section{N. Müller $(\bowtie) \cdot$ W. Kuttler $\cdot$ A.-B. Barlag}

Applied Climatology and Landscape Ecology,

University of Duisburg-Essen, Schützenbahn 70,

45127 Essen, Germany

e-mail: nicole.mueller@uni-due.de in heat waves, hot days, and tropical nights (MUNLV 2010). Long-term mitigation and adaptation measures to reduce the summer heat load are therefore needed. Based on the example of Oberhausen, a medium-sized town in the center of this region, measures leading to a reduction of urban heat stress and their effectiveness were investigated. This town and the analysis were included in the project dynaklim ${ }^{1}$. The physiologically equivalent temperature (PET; Höppe 1999; Matzarakis et al. 1999; Mayer and Höppe 1987) thermal comfort index was employed for evaluation.

A common adaptation measure, for example, is to produce an increase in so-called "blue and green infrastructure" (Allen 2012; Gill et al. 2007), a term used to describe evaporation areas (i.e., water and vegetation) which, by evapotranspiration, improve thermal comfort by reducing air temperature and increasing humidity. In addition, reduction of the surface temperatures $\left(t_{\text {surf }}\right)$ of shaded ground and building surfaces as well as vegetation and water surfaces can further decrease turbulent and convective heat transport and thus contribute to achieving a diminution of thermal discomfort (Shashua-Bar et al. 2011; Spronken-Smith and Oke 1999). Measures to provide shade are also the focus of some analyses. Shade can be provided by vegetation elements, especially trees (e.g., Oliveira et al. 2011; Georgi and Dimitriou 2010; Shashua-Bar et al. 2009; Streiling and Matzarakis 2003) and buildings (Shashua-Bar et al. 2012; Thorsson et al. 2011; Oliveira et al. 2011; Ali-Toudert and Mayer 2007). Findings have also been reported on the effects of surfaces of different vegetation types and vegetation densities on thermal comfort (e.g., Charalampopoulos et al. 2012; Cohen et al. 2012; Lin et al. 2008; Potchter et al. 2006; Ali-Toudert and Mayer 2005) as well as the effects of water surfaces (e.g., Sun and Chen 2012; Xu et al. 2010; Krüger and Pearlmutter 2008; Saaroni and Ziv

\footnotetext{
${ }^{1}$ dynaklim: Dynamic adaptation to the effects of climate change in the Emscher-Lippe region (Ruhr area); see www.dynaklim.de.
} 
2003). Comparative studies on the effectiveness of vegetated areas on the one hand and water surfaces, on the other hand, however, are rare (e.g., Mahmoud 2011). It is not only influences on the target-affected areas themselves that are of great interest but also the possible climate-positive effect on surrounding areas and the quantification of their effectiveness for urban planning.

In this study, thermal comfort in urban areas with different proportions of green and water areas was investigated through meteorological measurements. To standardize the observations, different local climate zones (LCZs; after Stewart 2011) were considered. In addition, the small-scale effects of different adaptation measures were analyzed in an exemplary model simulation in a representative downtown district of the model city.

In addition, changes in meteorological constraints and other parameters were included in the analysis as, for example, vegetation areas require an adequate water supply to fulfill their evapotranspiration potential and have positive effects on thermal comfort, especially during heat waves (Goldbach and Kuttler 2012; Spronken-Smith and Oke 1998). Wind speed affects thermal comfort in urban areas and the strength of UHI formations. In this study, we also examined ventilation, especially during indigenous weather conditions (clear and calm days), as it is particularly important for city planning (e.g., Barlag and Kuttler 1990/91).

\section{Materials and methods}

\subsection{Study area and measurement setup}

The study area was the western German city of Oberhausen (213,000 inhabitants, $77 \mathrm{~km}^{2}$; IT.NRW 2011a) in the Ruhr metropolitan region. The mean annual air temperature of Oberhausen is $10.9^{\circ} \mathrm{C}$, with a mean value of $18.9^{\circ} \mathrm{C}$ in July, the warmest month, and a mean of $3.1{ }^{\circ} \mathrm{C}$ in January, the coldest month (DWD 2011). Oberhausen has a mean annual rainfall of $767 \mathrm{~mm}$ (personal communication; EGLV 2011). The main wind direction is southwest to west (LANUV nd). For the 14-month study period (7 July 2010-13 September 2011), a meteorological monitoring network made up of eight stations in surface structures within different LCZs was installed as part of the project dynaklim (Fig. 1 and Table 1); the stations represent the typical land use structures of the project region (see Kuttler et al. 2012a). Continuously measured values during the period from 1 August 2010 to 31 July 2011 served as reference standards for the analysis. Using this measurement network, the effect of different, real evaporation areas within the urban boundary layer can be shown. At all stations, combined temperature and humidity sensors (Pt100, capacitive sensing element) in radiation shelters were used to record air temperature $\left(t_{a}\right)$ and relative humidity $(r H)$ data at a height of approximately $3.4 \mathrm{~m}$; cup anemometers and wind vanes were used to collect wind speed $(W S)$ and wind direction $(W D)$ data $3.8 \mathrm{~m}$ above ground. Soil temperatures (Pt100) were simultaneously measured at different depths $(0.01-1.95 \mathrm{~m})$ near the meteorological stations (cf. Kuttler et al. 2012b). These data were used simultaneously as input for the model.

\subsection{Thermal comfort}

Thermal comfort can be determined using the PET comfort index (Höppe 1999) among other thermal indices used in human biometeorology (cf. Jendritzky et al. 2012). The PET index assesses thermal comfort (Table 2) by taking into account thermal-hygric conditions, radiation and wind data, the human metabolic heat exchange rate, and other individual-related parameters (e.g., age, gender, and clothing), allowing a comprehensive assessment of the effectiveness of the adaptation measures. The Universal Thermal Climate Index (UTCI; Jendritzky et al. 2012) was not used in this study because it is not supported by the ENVI-met model (described below).

RayMan Pro version 2.1 software (Matzarakis 2010) was used to calculate PET values from the measured data. This software is well suited for determining microclimatic changes in different urban structures, as it calculates the radiation fluxes of different surfaces and their changes (Gulyàs et al. 2006). The mean radiant temperature $\left(t_{\mathrm{mrt}}\right)$ is slightly underestimated by RayMan when the sun is low in the sky (Matzarakis et al. 2010; Thorsson et al. 2007). In locations with a relatively high position of the sun, simulation results of $t_{\mathrm{mrt}}$ by RayMan are quite good, as a study of Lin et al. (2010) showed in Taiwan. In the present study, only 1 day with high summer sun position was considered. Therefore, the results are expected to be reliable. Moreover, RayMan has often been used in studies conducted in midlatitude cities with similar conditions (cf. Kántor and Unger 2010; Matzarakis et al. 2007).

The RayMan software was driven by observed meteorological data for $t_{a}, r H$, and $W S$ (see Table 8 in the "Appendix" section). To determine the sky view factor, fisheye photos of the vegetation period in May 2011 were utilized. For the input of human parameters (e.g., activity, clothing, age, and gender), the same values were used, which also served as the basis for the PET calculations in the simulation runs of the ENVI-met model (see Table 8 in the "Appendix" section).

\subsection{Model simulation}

For the model simulations, the three-dimensional, numerical, ENVI-met microscale climate model (version 3.2; Bruse 
Fig. 1 Overview of land use, climate station monitoring network, and the model area in Oberhausen, Germany (base map: Stadt Oberhausen 2012)

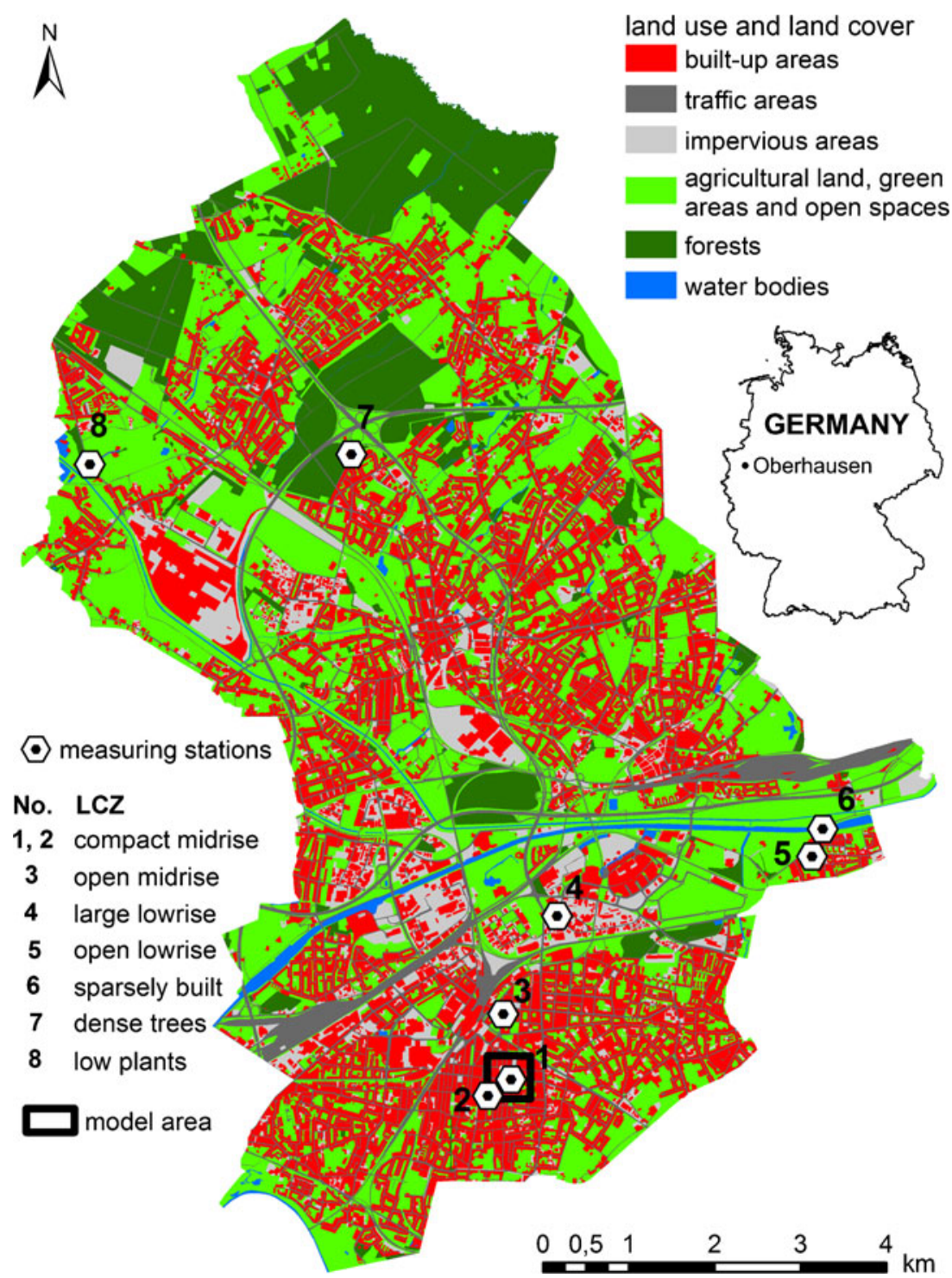

Table 1 Descriptive parameters of measuring stations in Oberhausen

\begin{tabular}{|c|c|c|c|c|c|c|c|c|c|c|}
\hline No. & $\mathrm{LCZ}$ & $\lambda_{b}$ & $\lambda_{i}$ & $\lambda_{p}$ & $H$ & $S V F$ & $t_{a}$ & $r H$ & $W S$ & $W D$ \\
\hline 1 & 2-Compact midrise (highly sealed) & 0.7 & 0.2 & 0.1 & 15 & 0.7 & 11.3 & 72.9 & 0.6 & $\mathrm{~W}$ \\
\hline 2 & 2-Compact midrise & 0.6 & 0.3 & 0.1 & 15 & 0.8 & 11.1 & 73.7 & 1.5 & SSW \\
\hline 3 & 5-Open midrise & 0.3 & 0.4 & 0.4 & 15 & 0.7 & 10.7 & 76.6 & 0.6 & SSW \\
\hline 4 & 8-Large lowrise & 0.3 & 0.5 & 0.2 & 9 & 0.9 & 10.8 & 74.7 & 1.4 & SSW \\
\hline 5 & 6-Open low rise & 0.3 & 0.1 & 0.6 & 11 & 0.8 & 10.6 & 77.1 & 0.7 & W \\
\hline 6 & 9-Sparsely built & 0.1 & 0.1 & 0.8 & 11 & 0.8 & 10.5 & 78.2 & 2.0 & WSW \\
\hline 7 & $\mathrm{~A}-$ dense trees & 0.2 & 0.2 & 0.7 & 6 & 0.1 & 10.2 & 79.7 & 0.3 & SSW \\
\hline 8 & $\mathrm{D}$-low plants & 0.1 & 0.1 & 0.9 & 6 & 0.8 & 10.3 & 79.2 & 1.0 & W \\
\hline
\end{tabular}

no. station number, $L C Z$ local climate zone after Stewart (2011), $\lambda_{b}$ built surface fraction in a 21-ha grid square surrounding the stations thus corresponding with the size of the modeled area, $\lambda_{i}$ impervious surface fraction, $\lambda_{p}$ pervious surface fraction, $H$ mean building height in meter, $S V F$ sky view factor; mean values (1 August 2010 - 31 July 2011) of $t_{a}=$ air temperature in degree Celsius, $r H$ relative humidity in percent, $W S$ wind speed in meter per second, $W D$ wind direction 
Table 2 PET evaluation scale (Matzarakis and Mayer 1996; modified)

\begin{tabular}{lll}
\hline PET in ${ }^{\circ} \mathrm{C}$ & Thermal perception & Stress stage \\
\hline$<4$ & Very cold & Extreme cold stress \\
$4-8$ & Cold & Great cold stress \\
$8-13$ & Cool & Moderate cold stress \\
$13-18$ & Slightly cool & Slight cold stress \\
$18-23$ & Comfortable & No thermal stress \\
$23-29$ & Slightly warm & Slight heat stress \\
$29-35$ & Warm & Moderate heat stress \\
$35-41$ & Hot & Great heat stress \\
$>41$ & Very hot & Extreme heat stress \\
\hline
\end{tabular}

2010; personal communication) was used. This model is based on the laws of flow and thermodynamics, and it calculates the atmospheric state and its changes over time through a combination of soil, vegetation, and atmospheric models (Bruse and Fleer 1998). The illustration of real urban structures was developed from a digital threedimensional spatial grid whereby buildings, vegetation structures, and surface elements were simplified by model blocks. The maximum spatial resolution of the model is $250 \times 250 \times 30$ grid cells and is limited by the relatively high computing time of the transient used model (Bruse 2000). With a geometric resolution between 0.5 and $10 \mathrm{~m}$, a smallscale simulation of neighborhoods is possible (Huttner et al. 2009). For PET calculation, the calcPET tool of ENVI-met was applied, additionally.

For the digitization of the model area, digital orthophotos (IT.NRW 2011b), building and vegetation heights of a digital surface model (Bezirksregierung Köln 2010) were used. The simulations were performed for a hot day $\left(t_{\max }>30^{\circ} \mathrm{C}\right)$ under indigenous conditions. The $t_{a}$ and $r H$ diurnal variations of the downtown station (LCZ compact midrise, station 1; see Fig. 1 for location) of the monitoring network served as input data. In addition, soil temperature data from the ground monitoring station near station 1 were used (Püllen 2010; personal communication). The analysis and model validation took place on an hourly basis. The other model input parameters are shown in Table 8 in the "Appendix" section.

\subsection{Scenario setup}

The LCZ compact midrise (1) was chosen as a model area for the simulations because it currently has the highest thermal loads in the model city. Overall, the model has a surface area of 21 ha $(460 \times 460 \mathrm{~m})$ with station 1 in the center (Fig. 2). To simulate adaptation scenarios in the model area, portions of the buildings $\left(12,000 \mathrm{~m}^{2} \approx 1-2\right.$ building blocks and average surface area of urban parks in Central Europe (Bongardt 2006)) were replaced by unsealed surfaces such as water, grass, parks, and forest areas (Fig. 2 and Table 3). Relatively small areas similar to these can be converted by actual structural land use changes in cities (e.g., abandonment of industrial areas or changes in population structure, e.g., "shrinking cities"). Moreover, the effects of changes in meteorological and building-specific input parameters for different scenarios were checked (Table 3; the changed values of the input parameters are shown in Table 8 in the "Appendix" section).

\subsection{Model evaluation}

An evaluation of the model results was performed by comparing the measured and modeled diurnal variations of $t_{a}$ and $\mathrm{rH}$, whereby the former were also used as input data.
Fig. 2 Model area, LCZ compact midrise (1), with scenario plots

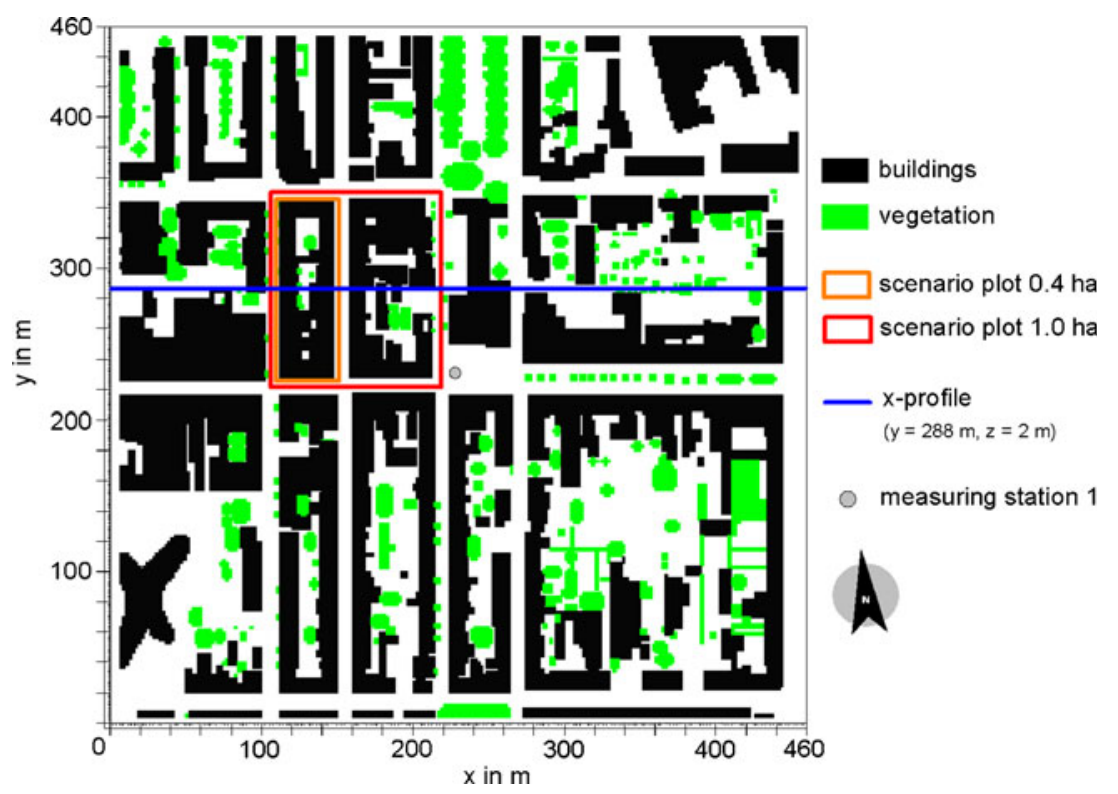


Table 3 Summary and description of all simulated model scenarios (the values of the modified parameters are listed in Table 8 in the Appendix)

\begin{tabular}{ll}
\hline Scenario names & Descriptions of scenarios \\
\hline Current condition & \\
Base case & Original/real state without any changes \\
Initial vegetation and water cases & \\
Grass 1 ha & Substitution of a built-up area of about 1 ha by grass (lawn) \\
Park 1 ha & Substitution of a built-up area of about 1 ha by a park \\
& (savanna type: lawn with scattered trees) \\
Forest 1 ha & Substitution of a built-up area of about 1 ha by a forest (dense trees) \\
Water 1 ha & Substitution of a built-up area of about 1 ha by a water body \\
Park 0.4 ha & Substitution of a built-up area of 0.4 ha by a park \\
& (savanna type: lawn with scattered trees) \\
Water 0.4 ha & Substitution of a built-up area of 0.4 ha by a water body \\
Modified meteorological and pedological boundary conditions \\
Base case WS $2 \mathrm{~m} / \mathrm{s}$ & As base case + wind speed $2 \mathrm{~m} / \mathrm{s}$ \\
Park WS $2 \mathrm{~m} / \mathrm{s}$ & As scenario park 1 ha + wind speed $2 \mathrm{~m} / \mathrm{s}$ \\
Water WS $2 \mathrm{~m} / \mathrm{s}$ & As scenario water 1 ha + wind speed $2 \mathrm{~m} / \mathrm{s}$ \\
Base case WS $3 \mathrm{~m} / \mathrm{s}$ & As base case + wind speed $3 \mathrm{~m} / \mathrm{s}$ \\
Park WS $3 \mathrm{~m} / \mathrm{s}$ & As scenario park 1 ha + wind speed $3 \mathrm{~m} / \mathrm{s}$ \\
Water WS $3 \mathrm{~m} / \mathrm{s}$ & As scenario water 1 ha + wind speed $3 \mathrm{~m} / \mathrm{s}$ \\
Park SM low & As scenario park 1 ha + soil moisture content: low \\
Park SM high & As scenario park 1 ha + soil moisture content: high \\
Modified building parameters & As base case + modified albedo \\
Albedo & As base case + roof greening on all roofs in the whole model area \\
Roof greening whole area & building height)
\end{tabular}

The analyses are divided into a daily initialization period (day 1, 19 model hours-start time of the simulation with initial values, 4 CET) and a diurnal course chosen for evaluation (day 2, 24 model hours) because the simulation period was $44 \mathrm{~h}$ long. To evaluate the model performance, the coefficient of determination $\left(r^{2}\right)$ of the direct comparison of measured and modeled data for $t_{a}$ and $r H$ for the 24 individual hourly values of the diurnal course chosen for evaluation (day 2) were used (Fig. 3). Both parameters $\left(t_{a}\right.$ and $r H$ ) had a variance of $r^{2}>0.9$; thus, they reproduced the observed values well. The accuracy of the model could also be confirmed by the simulation results of two more LCZs, namely, open lowrise (5) and low plants (8) $\left(r^{2}>0.9\right.$ both for $t_{a}$ and $r H$, not shown here).

Furthermore, Ng et al. (2012) and Chow et al. (2011) confirmed satisfactory model results especially for $t_{a}$, as well as Krüger and Pearlmutter (2008) for WS. Whereas, Carnielo and Zinzi (2013) due to model inaccuracies propose the comparison of relative reductions of different cases instead of considering absolute values. So, Yang et al. (2011) stated, for example, that $t_{\mathrm{mrt}}$ is overestimated by ENVI-met due to overestimation of solar radiation and surface temperature, the latter, because the heat storage of buildings is not taken into account by the model. Ali-
Fig. 3 Scatter plot of measured and model data analysis of the diurnal course chosen for evaluation (day 2); a air temperature $\left(t_{a}\right)$, b relative humidity $(\mathrm{rH}))$
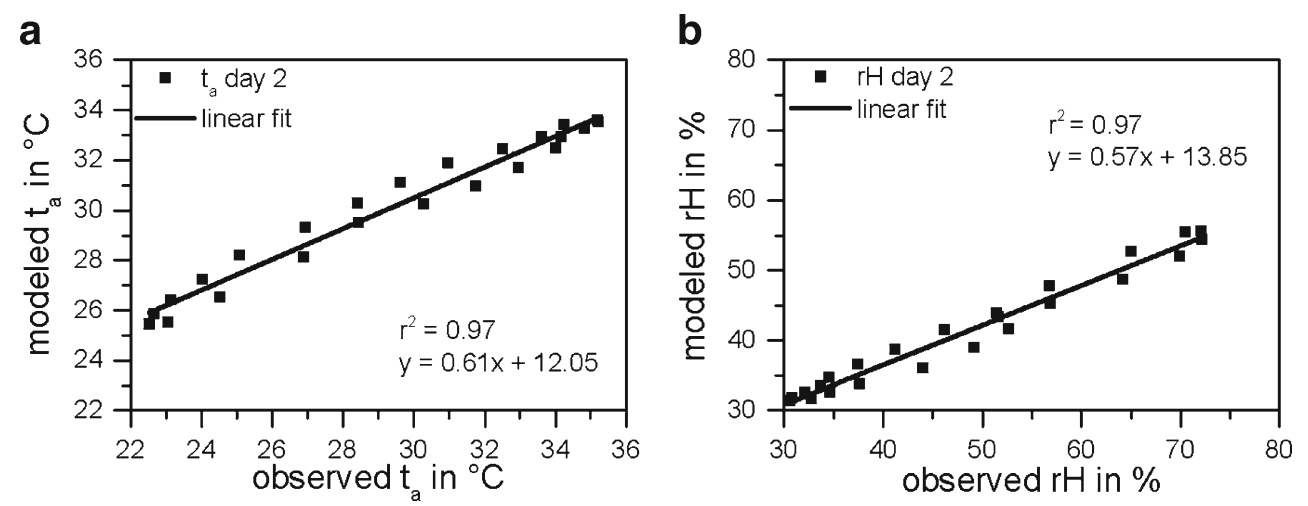
Toudert (2005) also showed overestimation of radiation fluxes and identified a systematic error in the model simulations. To reduce this error, it is possible to adjust solar access of the ENVI-met model. In contrast to Ali-Toudert (2005), who achieved a quite good accordance between measurements and model simulations of $t_{\mathrm{mrt}}$ by adjusting solar access, the values could not be adapted within the frames of this analysis, due to the missing possibility to verify them by measurements. To compensate the overestimation of the computed PET values especially in the daytime situation (16 CET) due to overestimation of the solar radiation, the PET values were corrected for analysis by linear regression of the measured and modeled data in this study. Moreover, recent model developments show that the use of forcing for different parameters can also increase the conformity of modeled and measured values as shown by Huttner (2012). Unfortunately in the applied model version, forcing was only possible for $t_{a}$ and $r H$, which showed a good accordance with the measurement values in this analysis (Fig. 3).

\section{Results}

The results for the network measurements and model simulation analysis are presented separately. The differences in thermal comfort in distinct LCZs were first revealed using a PET diurnal course and an analysis of climatic event days. The model simulations of the adaptation scenarios with their respective effects were then compared with the base case $\left(\mathrm{PET}_{\text {plan scenario }}-\mathrm{PET}_{\text {base case }}\right)$.

\subsection{Classification of thermal sensation in different LCZs}

An analysis of climatic event days (Table 4) underscored differences between the LCZs throughout the year. It is noteworthy that tropical and warm nights were observed in the LCZs (Table 4), as night temperatures play an important role in human health and recreation. High nocturnal PET values can lead to decreased sleeping comfort and a higher mortality, especially during heat waves (e.g., Laaidi et al. 2012). Such effects are amplified during prolonged heat waves, when the daily minimum and maximum temperatures increase with heat wave duration (Kuttler 2012). A clear differentiation was apparent in the nightly threshold values between the compact midrise (1 and 2) and large lowrise (4) LCZs and the sparsely built (6), dense trees (7), and low plants (8) LCZs (Table 4).

The densely built LCZ compact midrise (1) show particularly high thermal loads during hot days $\left(t_{a \max }>30^{\circ} \mathrm{C}\right)$, as shown by the comparative analysis of a PET diurnal course (10 July 2010) for all stations (Fig. 4). Very high PET values were also obtained for the open midrise (3) and open lowrise (5) LCZs. Conversely, areas without a substantial building effect, namely the sparsely built (6) and dense trees (7) LCZs, rarely exceed the highest load levels during the day. The afternoon decline and rise in PET in the compact midrise (1 and 2) and open midrise (3) LCZs are due to the shadowing effects of buildings in the vicinity of the stations. At night, the highest PET values can be seen under dense trees in LCZ 7 (Fig. 4), whereas the vegetated LCZs low plants (8), sparsely built (6) and open low rise (5) show a slight deviation below the comfort range.

\subsection{Classification of adaptation scenarios}

To analyze the model simulations, values of 4 CET (minimum $t_{a}$ of summer days) and 16 CET (maximum $t_{a}$ of summer days) were used. The results were analyzed $2 \mathrm{~m}$ above ground level, as an $x$-profile (EW section, $y=288 \mathrm{~m}$ and $z=2 \mathrm{~m}$ (representing the average PET values of the lowest grid cell)) that runs centrally through the changing surface for the 1-ha scenarios (see Fig. 2). The effects of the respective simulated values relative to the base case values $\left(\mathrm{PET}_{\text {plan }}\right.$ scenario $\left.-\mathrm{PET}_{\text {base case }}\right)$ are reported here.

Table 4 Frequency of occurrence of climatic event days in the LCZs in Oberhausen during the measurement period (1 August 2010-31 July 2011)

\begin{tabular}{|c|c|c|c|c|c|c|c|c|}
\hline No. & $\mathrm{LCZ}$ & $\begin{array}{l}\text { Hot days } \\
t_{a \max } \geq 30{ }^{\circ} \mathrm{C}\end{array}$ & $\begin{array}{l}\text { Summer days } \\
t_{a \max } \geq 25^{\circ} \mathrm{C}\end{array}$ & $\begin{array}{l}\text { Tropical nights } \\
t_{a \min }>20^{\circ} \mathrm{C}\end{array}$ & $\begin{array}{l}\text { Warm nights } \\
t_{a 0 \mathrm{CET}}>20^{\circ} \mathrm{C}\end{array}$ & $\begin{array}{l}\mathrm{BBQ} \text { days } \\
t_{a 21 \mathrm{CET}}>20^{\circ} \mathrm{C}\end{array}$ & $\begin{array}{l}\text { Frost days } \\
t_{a \min }<0{ }^{\circ} \mathrm{C}\end{array}$ & $\begin{array}{l}\text { Ice days } \\
t_{a \text { max }}<0{ }^{\circ} \mathrm{C}\end{array}$ \\
\hline 1 & $\begin{array}{l}\text { Compact midrise } \\
\text { (highly sealed) }\end{array}$ & 3 & 35 & 2 & 12 & 40 & 51 & 18 \\
\hline 2 & Compact midrise & 3 & 24 & 2 & 12 & 42 & 55 & 18 \\
\hline 3 & Open midrise & 3 & 26 & 1 & 9 & 25 & 60 & 18 \\
\hline 4 & Large lowrise & 3 & 25 & 2 & 12 & 33 & 59 & 18 \\
\hline 5 & Open lowrise & 3 & 29 & 0 & 8 & 26 & 69 & 19 \\
\hline 6 & Sparsely built & 3 & 19 & 0 & 6 & 25 & 61 & 17 \\
\hline 7 & Dense trees & 2 & 16 & 0 & 5 & 16 & 64 & 19 \\
\hline 8 & Low plants & 3 & 23 & 0 & 5 & 17 & 72 & 19 \\
\hline
\end{tabular}

$B B Q$ barbeque 
Fig. 4 Diurnal variation of PET values (see Table 2) at the climate stations of the monitoring network in Oberhausen on 10 July 2010 , based on measurements of the station monitoring network (see Fig. 1)

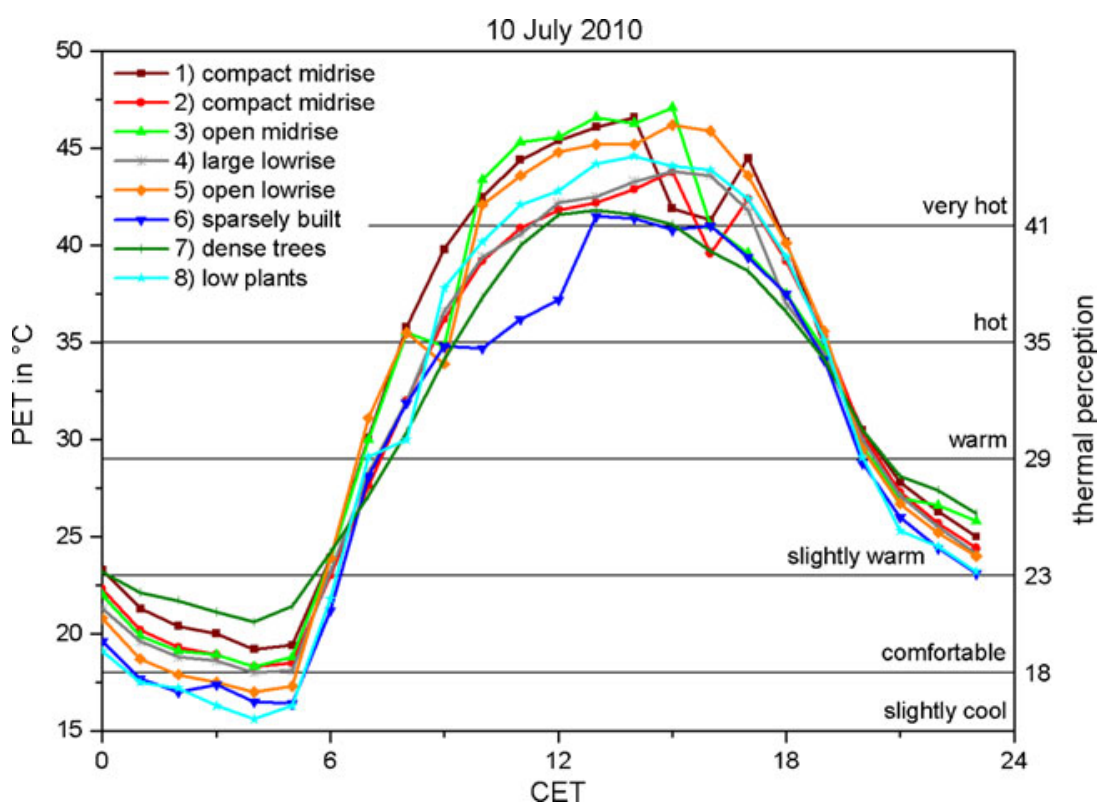

Tables 5 and 6 show the PET differences from the base case as the maximum and average values of the EW-section at night and during the day for all scenarios. As Table 5 shows, there is no detectable effect on thermal comfort at night for the scenario roof greening whole area and albedo ("detectable effect" is defined herein as a modification of PET of more than $\pm 0.5 \mathrm{~K}$ ). During the day, however, the scenario roof greening whole area achieved a reduction of PET, thus improving thermal comfort (about $-2.5 \mathrm{~K}$; Table 6). However, the average PET differences of the two scenarios mentioned above are hardly detectable over the entire $x$-profile.

Table 5 Average and maximum PET reduction effects of all scenarios in relation to the base case ( $\mathrm{PET}_{\text {plan scenario }}-\mathrm{PET}_{\text {base case }}$ ) along $x$-profile $(y=288 \mathrm{~m}, z=2 \mathrm{~m})$ at $4 \mathrm{CET}$

Plan scenarios Average reduction Maximum reduction effect in $\mathrm{K} \quad$ effect in $\mathrm{K}$

\begin{tabular}{lll}
\hline Albedo & 0.00 & -0.07 \\
Roof greening whole area & -0.02 & -0.14 \\
Water 0.4 ha & -0.10 & -2.54 \\
Park 0.4 ha & -0.21 & -2.75 \\
Water 1 ha & -0.39 & -3.80 \\
Grass 1 ha & -0.43 & -3.90 \\
Park SM high & -0.46 & -3.56 \\
Park SM low & -0.48 & -3.82 \\
Park 1 ha & -0.51 & -3.69 \\
Forest 1 ha & -0.55 & -3.58 \\
Base c. WS 2 m/s & -1.26 & -1.70 \\
Water WS $2 \mathrm{~m} / \mathrm{s}$ & -1.65 & -5.28 \\
Park WS $2 \mathrm{~m} / \mathrm{s}$ & -1.69 & -5.02 \\
Base c. WS $3 \mathrm{~m} / \mathrm{s}$ & -1.86 & -2.57 \\
Water WS $3 \mathrm{~m} / \mathrm{s}$ & -2.23 & -5.76 \\
Park WS $3 \mathrm{~m} / \mathrm{s}$ & -2.24 & -5.64 \\
\hline
\end{tabular}

The initial water and vegetation scenarios achieved PET reductions in the range of 2.5-4 $\mathrm{K}$ at night. Therefore, the slightly warm conditions in the base case can be improved to comfortable conditions for the whole profile (Fig. 5). During the day, a strong differentiation of the effects of these scenarios appears. The high maximum PET reduction in scenario forest 1 ha $(>24 \mathrm{~K})$ can be ascribed to a reduction of $t_{\mathrm{mrt}}$ through shading and transpiration by the tree population (see Chapter 4). These strong reductions can be shown for park 1 ha and forest 1 ha not only compared to the base case, but especially in comparison to grass 1 ha and water 1 ha (Fig. 6). The highest reductions, $5 \mathrm{~K}$ at night and $15 \mathrm{~K}$ during the day, are shown for the scenarios with an increased initial wind speed.

The PET differences along the entire $x$-profile for the 1-ha vegetation and water scenarios are shown in Figs. 5 and 6. No changes occur east of the modified surface (windward), while the largest reductions (approximately $4 \mathrm{~K}$ at night and up to $15 \mathrm{~K}$ during the day, except forest 1 ha: $24 \mathrm{~K}$ ) are achieved over the changing surface itself. Due to low wind speeds in the initial cases in this clear and calm day, almost no air exchange occurs, so the cooler and more humid air, which is generated by the modified area itself, can hardly be transported into the built-up surroundings. Nevertheless, downwind (W) of the modified area, a slight PET-reducing effect on the environment is obtained. This effect reaches a PET reduction of $0.5 \mathrm{~K}$ at night in the park 1 ha and forest 1 ha scenarios, at a distance of up to $90 \mathrm{~m}$ from the modified surface. During the day, however, the scenario water 1 ha has the strongest long distance effect, with PET reductions greater than $0.5 \mathrm{~K}$ up to $80 \mathrm{~m}$ away. The PET increases over the modified area in locations shaded by buildings in the base case scenario.

The effects of changes in meteorological boundary conditions are presented in detail in Fig. 7. In the night situation, all soil moisture scenarios (Fig. 7a) show a reduction of thermal stress 
Table 6 Average and maximum PET reduction effects of all scenarios in relation to the base case $\left(\mathrm{PET}_{\text {plan scenario }}-\mathrm{PET}_{\text {base case }}\right.$ ) along $x$ profile $(y=288 \mathrm{~m}, z=2 \mathrm{~m})$ at $16 \mathrm{CET}$

\begin{tabular}{lcc}
\hline Plan scenarios & $\begin{array}{c}\text { Average reduction } \\
\text { effect in K }\end{array}$ & $\begin{array}{l}\text { Maximum reduction } \\
\text { effect in K }\end{array}$ \\
\hline Water 0.4 ha & 0.67 & -0.92 \\
Grass 1 ha & 0.59 & -12.46 \\
Park SM low & 0.45 & -11.42 \\
Water 1 ha & 0.42 & -14.90 \\
Park 0.4 ha & 0.30 & -1.51 \\
Park 1 ha & 0.10 & -12.00 \\
Albedo & -0.02 & -0.42 \\
Roof greening whole area & -0.16 & -2.44 \\
Park SM high & -0.31 & -14.21 \\
Forest 1 ha & -0.86 & -24.08 \\
Water WS 2 m/s & -1.17 & -15.01 \\
Park WS 2 m/s & -1.52 & -12.85 \\
Water WS $3 \mathrm{~m} / \mathrm{s}$ & -1.72 & -15.04 \\
Base c. WS 2 m/s & -1.72 & -5.13 \\
Park WS, 3 m/s & -2.06 & -13.88 \\
Base c. WS, 3 m/s & -2.34 & -7.19 \\
\hline
\end{tabular}

from slightly warm to comfortable, whereas the PET reduction effect in the park SM low scenario is slightly higher than that for the park 1 ha and park SM high scenarios. Here too, the strongest reductions occur above the changed area itself but also over other existing areas of vegetation in the profile section. Downwind of the modified area, a slight PET reduction effect for the environment is obtained for all soil humidity scenarios. During the day, the sequence of the scenarios reverses (Fig. 7b), and the strongest PET reductions are achieved in the park SM high scenario. Overall, higher PET reductions occur during the day than during the night, particularly over the changed area and the more extended vegetation areas. The differences between the scenarios are also more prominent during the day.

Increased wind speed is effective throughout the profile both during the day and at night (Fig. 7c, d). Thus, average PET reductions of $2 \mathrm{~K}$ during the night and day are achieved (Tables 5 and 6). An improvement of thermal comfort from slightly warm to comfortable in the night situation and from very hot to hot or warm in the day-time situation is reached. The effectiveness of the PET reduction rises with increasing wind speed. Overall, the scenarios with increased wind speed show significantly higher PET reduction effects than any other adaptation strategy modeled here.

\section{Discussion}

From the results of the meteorological measurements and model simulations, various factors regarding the thermal comfort can be derived, which are discussed below.

\subsection{Effects of vegetation and water surfaces}

At night, grasslands represent the coldest areas of all the different types of vegetation due to low vegetation cover and a negative radiation balance. The highest PET values at night, however, are obtained in the dense trees (7) LCZ, as the effective long-wave radiation and wind speed are attenuated by the crown protection of the tree cover (Fig. 4). This result is consistent with an analysis of different structured city parks by Potchter et al. (2006).

During the day, the reduction in $t_{\mathrm{mrt}}$ by tree shading results in a lower thermal load in the dense trees LCZ as well as in the forest 1 ha scenario (cf. Mayer 2006), such that even the negative effects caused by the weakening of the wind speed can be compensated. High PET reductions (up to $20 \mathrm{~K}$ ) by tree-shaded areas have been confirmed with model simulations (Ali-Toudert 2005) as well as comparative measurements between tree-shaded and sun-exposed areas, as shown by Cohen et al. (2012), Oliveira et al. (2011), Mayer et al. (2009), Gulyás et al. (2006), and Streiling and Matzarakis (2003), among others. The thermal load of unshaded areas of vegetation is lower during the day than the load of unshaded paved areas, but it is far above the values of shaded areas. Oliveira et al. (2011) compared street canyon and park site pairs under sun and shade conditions and noted the park site always showed lower PET values than the street site (a 1.2 and 1.7 K PET difference under sun and shaded conditions, respectively), whereas differences between sunny and shady sites ranged between 10 and $17 \mathrm{~K}$ PET. Bongardt (2006) confirmed this pattern with recorded PET differences: the PET values on sunexposed roads were $2 \mathrm{~K}$ higher than those of grass surfaces and $10 \mathrm{~K}$ higher than those of shaded areas. Cohen et al. (2012) were able to demonstrate this effect via measurements of irrigated lawns as well. If unshaded, even water areas obtain high thermal loads $2 \mathrm{~m}$ above ground level during the daytime that cannot be compensated for by evaporation. However, Saaroni and Ziv (2003) showed that a pond has a positive effect on the thermal comfort of its surroundings. Accordingly, Mahmoud (2011) recommended tree shading in the vicinity of water bodies to reach the best thermal comfort environment for park users in summer situations.

The significant PET reduction effect of shading by a reduction of $t_{\mathrm{mrt}}$ can be caused by both vegetation and buildings (cf. Thorsson et al. 2011; Ali-Toudert and Mayer 2007). This is the reason for the daily negative effect on the profile average for the water and vegetation scenarios (except for forest $1 \mathrm{ha}$ ), as evaporation effects in the unshaded water and vegetation scenarios cannot surpass the positive effects on PET produced by building shade in the base case (see Figs. 5 and 6). However, as stated above, Oliveira et al. (2011) showed that, overall, the PET values and air 
Fig. 5 PET differences

( PET $\left._{\text {plan scenario }}-\mathrm{PET}_{\text {base case }}\right)$ in the 1-ha vegetation and water scenarios ("scenario plot" depicts the portion of the changed area in profile)

compared to the base case (top, absolute values, interruptions of the line are caused by existing buildings in the profile) for an $x$-profile $(y=288 \mathrm{~m}, z=2 \mathrm{~m})$ at 4 CET
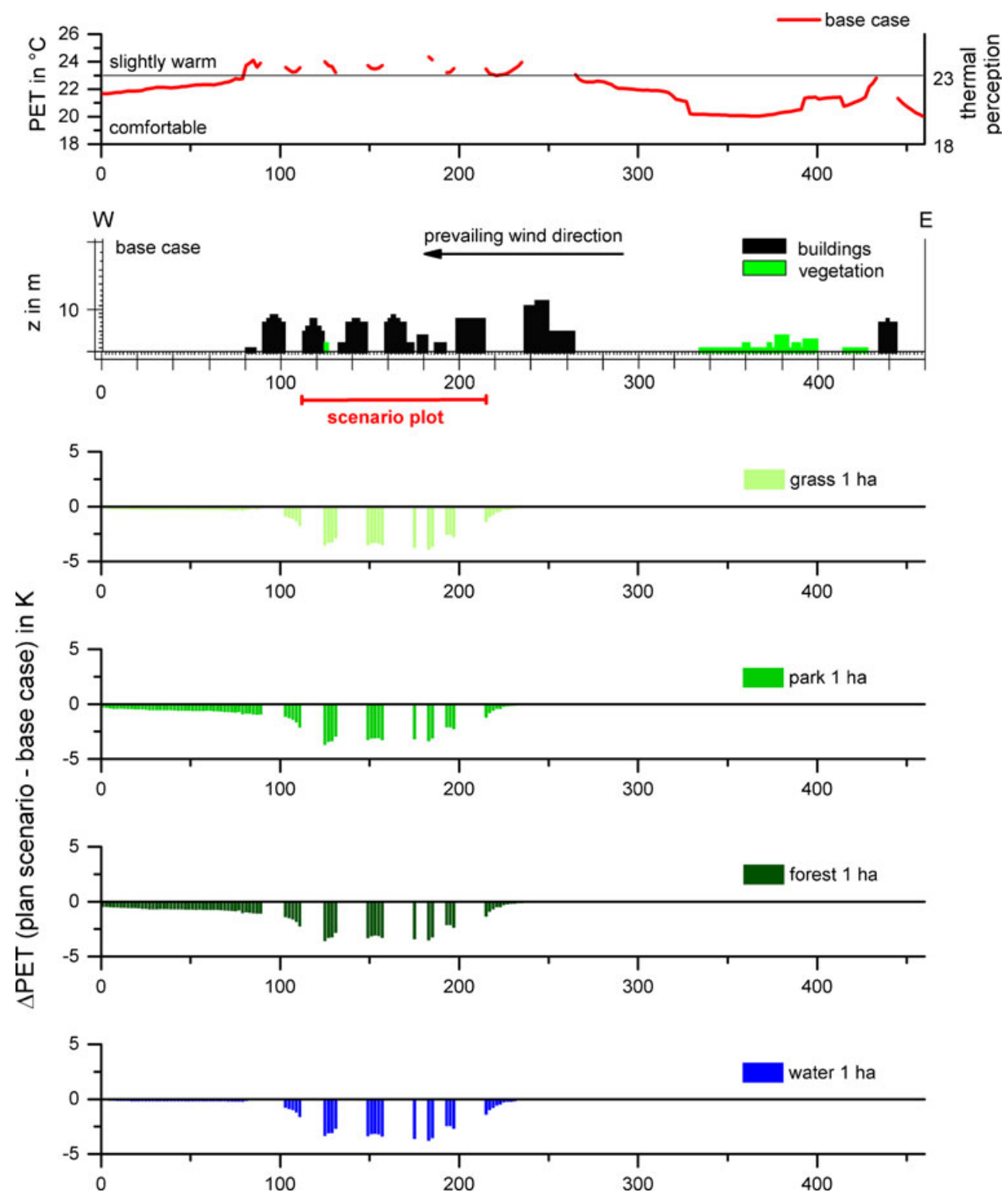

temperatures of shaded park areas are lower than those of street canyons shaded by buildings.

\subsection{Effects of changed pedological parameters}

Soil with a high water content (park SM high) provides for a slightly increased PET at night compared with non-irrigated (park SM low) or barely irrigated (park 1 ha) soil (Fig. 7a, for values see Table 8 in the "Appendix" section). This difference can largely be attributed to the higher thermal admittance of the wetter soil (Spronken-Smith and Oke 1998), whereas at night heat is not emitted as fast as from dry ground. During the day, however, soil with a high water content is not heated as strongly as poorly watered ground (see Huttner et al. 2009; Kuttler 2012). In addition, a PET reduction up to $3.5 \mathrm{~K}$ greater is achieved by higher evaporation from moist soil vis-a-vis soil with a low water content corresponding to the shift of thermal comfort classes from very hot to hot or hot to warm over the modified area (Fig. 7b). Conversely, Huttner et al. (2009) simulated approximately $8 \mathrm{~K}$ higher PET values in a worst-case scenario with dry soils at the end of a heat wave compared with a normal summer situation.

Thus, the small differences in thermal load between the open midrise (3) and compact midrise (1) LCZs (Fig. 4) are due to the insufficiently irrigated green areas (only $15 \mathrm{~mm}$ of precipitation from 1 June 2010 to 10 July 2010; personal communication; EGLV 2011) in the open midrise surroundings (3), which are barely able to achieve load-reducing effects by evapotranspiration (see Goldbach and Kuttler 2012). Furthermore, Goldbach (2012) showed that in a summer day situation with a good water supply, the PET difference between an urban and suburban station reached $10 \mathrm{~K}$ PET, but in 
Fig. 6 PET differences $\left(\mathrm{PET}_{\text {plan scenario }}-\mathrm{PET}_{\text {base case }}\right)$ in the 1-ha vegetation and water scenarios ("scenario plot" depicts the portion of the changed area in profile) compared to the base case (top, absolute values, interruptions of the line are caused by existing buildings in the profile) for an $x$-profile $(y=288 \mathrm{~m}, z=2 \mathrm{~m})$ at 16 CET
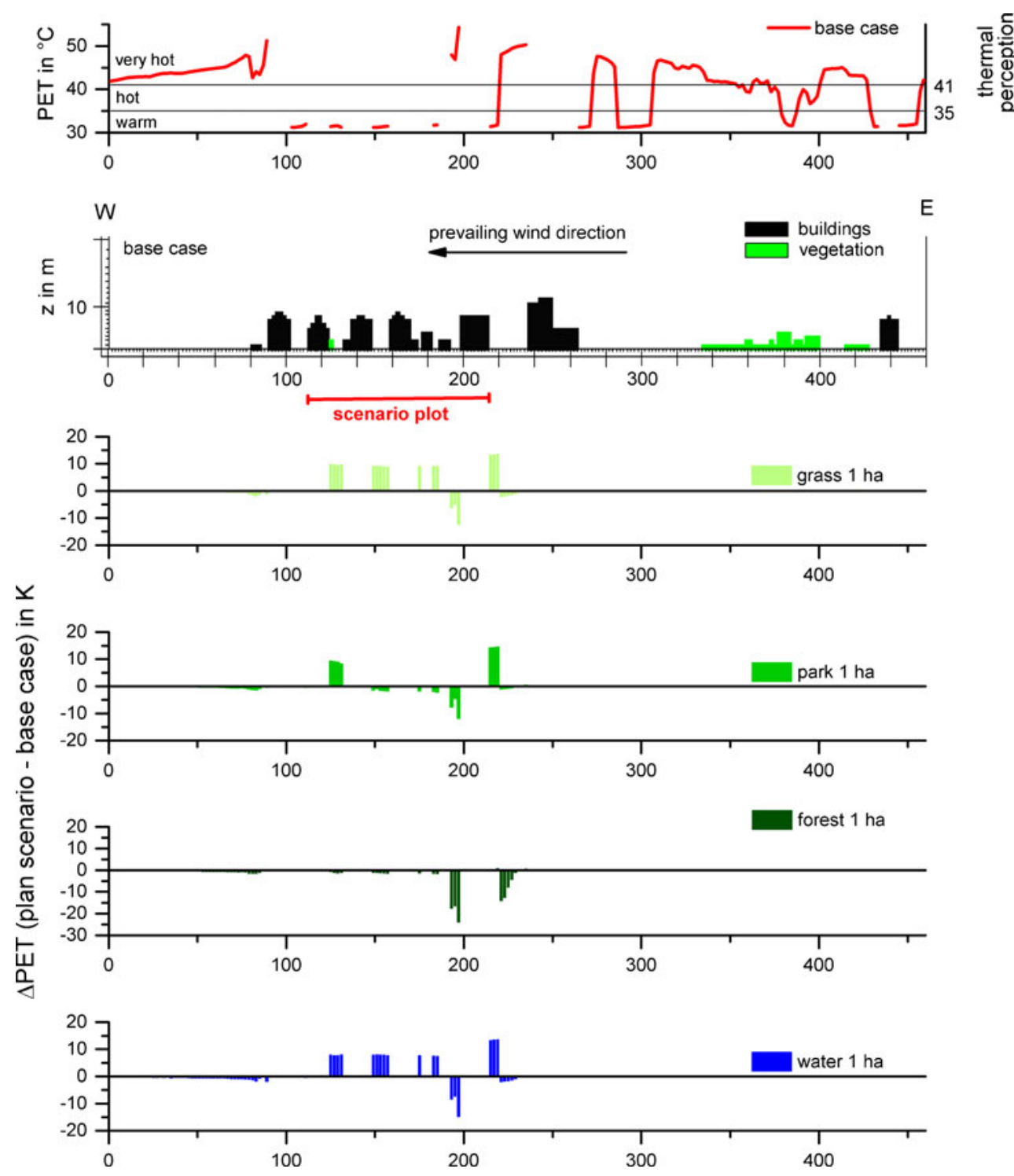

a "dry situation" a difference was hardly detectable between these stations.

\subsection{Effects of changes in meteorological parameters}

The scenarios with an increase in initial wind velocity show the highest PET reductions of all the scenarios (Tables 5 and 6 ) in the profile average ( $2 \mathrm{~K}$ PET reduction) as well as within the maximum values $(15 \mathrm{~K})$. This finding is comparable with data reported by Ali-Toudert (2005), whose simulation showed a maximum PET reduction of $12 \mathrm{~K}$ with a wind speed increase of $2-2.5 \mathrm{~m} / \mathrm{s}$. Based on long-term data, Matzarakis and Endler (2010) showed that small changes in wind speed of $\pm 1 \mathrm{~m} / \mathrm{s}$ caused the number of days exceeding the value of great heat stress to fall by approximately $3 \%$ or to rise by approximately $5 \%$. Thus, slight modifications of the wind speed have important effects on thermal comfort. As shown in Fig. 7c and d, the PET reduction even intensifies with increasing wind speed.

Significant effects of the wind speed are observed by the measurements as well. The relatively highly sealed station at compact midrise (2) shows lower thermal stress levels (approximately $-3 \mathrm{~K}$ PET) during the noon hours than the less densely built LCZs (Table 1, Fig. 4) due to its location on a major road junction, which allows for better ventilation at higher wind speeds. Lopes et al. (2011) also showed by measurements that a starting or increased sea breeze leads to a reduction in PET (up to $8 \mathrm{~K}$ ) and that this effect decreased with increasing distance from the coast. Svensson et al. (2003) observed similar results on a summer day, comparing two sites with almost equal $t_{a}$ values in the afternoon, found that the site with higher wind speed had lower PET values, although the site was in an industrial area. The model calculations performed in the present study also show that a combination of higher wind speed with an increase in the evaporation area fraction (water WS 2 and $3 \mathrm{~m} / \mathrm{s}$, park 2 and 
Fig. 7 PET values (absolute) of the scenarios with modified soil moisture and initial wind speed (interruptions of the line are caused by existing buildings in the profile) (top soil moisture scenarios (a and $\mathbf{b})$, bottom wind scenarios (c and $\mathbf{d})$, left situation at night 4 CET (a and c), right situation at day $16 \mathrm{CET}$ (b and d) for an $x$ profile $(y=$ $288 \mathrm{~m}, z=2 \mathrm{~m}$; modified values of meteorological parameters are listed in Table 8 in the "Appendix" section)

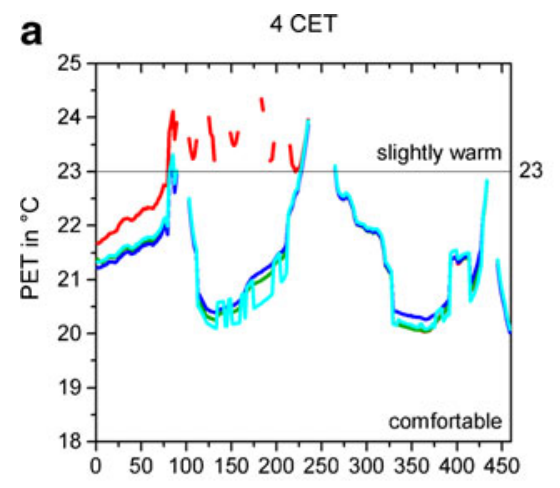

b

C

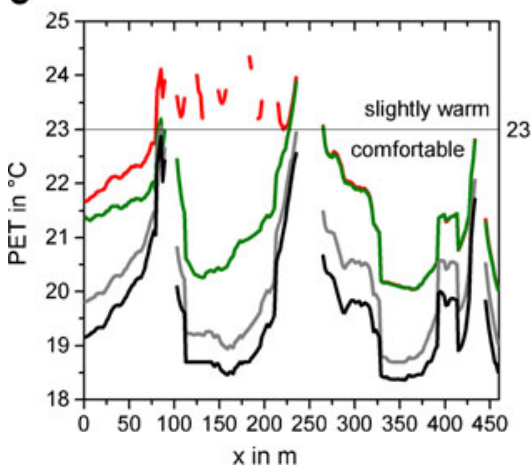

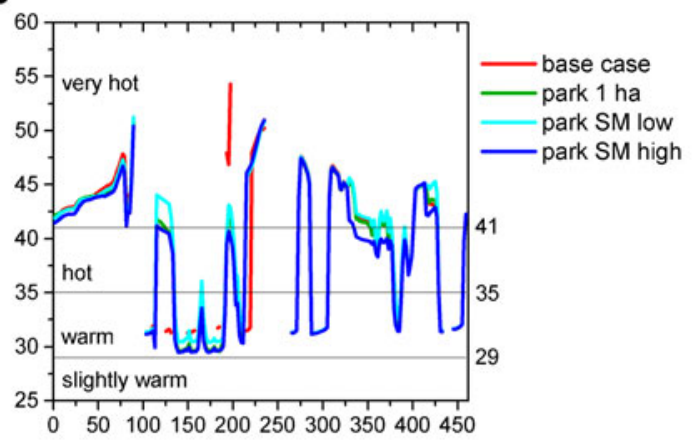

16 CET

d

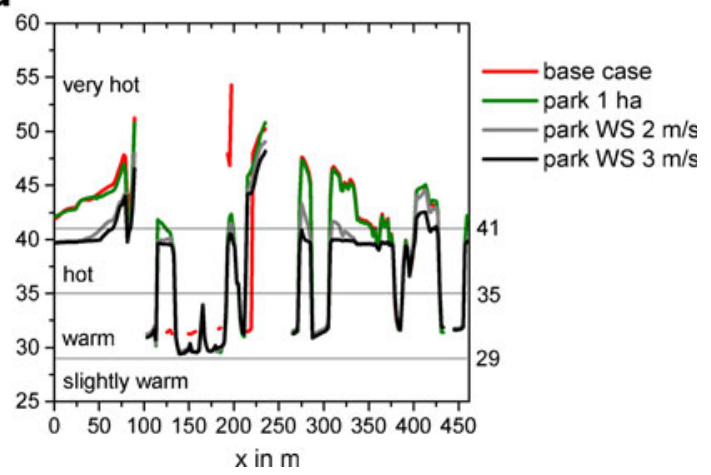

$3 \mathrm{~m} / \mathrm{s}$ scenarios) more strongly decreases thermal stress compared with increased initial wind speed alone (base case WS 2 and $3 \mathrm{~m} / \mathrm{s}$ scenarios).

\subsection{Downwind effects}

A temperature-reducing downwind effect of green spaces on nearby built-up areas has been shown previously by various authors, as summarized by Bongardt (2006) and Kuttler (2012). In our model simulations, downwind effects with a reduction of thermal pollution in dense environments can be observed, particularly in the water and vegetation scenarios. These scenarios reach PET reduction effects downwind of the modified surface within a range of $100 \mathrm{~m}$ due to the evaporation effects and transport of cool, moist air, whereby transport is possible despite low wind speeds, especially due to the low roughness of the water surface. Thus, Saaroni and Ziv (2003) showed air temperature reductions downwind of a pond (up to $40 \mathrm{~m}$ ) and a positive relationship between air temperature reduction and wind speed. Murakawa et al. (1990/01) also stated that air temperature reductions caused by river systems can be detected at a distance of a few hundred meters depending on building density, wind direction, and wind velocity. The simulation results of this study showed that downwind effects occurred particularly in the scenarios with increased wind speed (water WS 2 and $3 \mathrm{~m} / \mathrm{s}$, park 2 and $3 \mathrm{~m} / \mathrm{s}$, and base case WS 2 and $3 \mathrm{~m} / \mathrm{s}$ scenarios). No conclusions could be drawn about the absolute range of the effect due to the restricted size of the model area.

\subsection{Effects of changed building parameters}

The roof greening scenario shows that building roofs with heights between 10 and $18 \mathrm{~m}$ are too high to produce an effect at $2 \mathrm{~m}$ above ground level. $\mathrm{Ng}$ et al. (2012) showed identical results for green roofs at 20,40 , and $60 \mathrm{~m}$ building heights. If garages with building heights of $2-3 \mathrm{~m}$ are considered (roof greening whole area scenario), maximum PET reductions of approximately $2.5 \mathrm{~K}$ versus the base case are achieved. This result fits with the findings of Liang and Huang (2011). Using a model simulation, Gross (2012) also showed that the number of hot days over a green roof is considerably lower than over a conventional roof, and this effect was observed currently and in future scenarios. Moreover, green roofs, regardless of their height above ground, have a positive impact on the indoor environment of the houses (e.g., Kuttler 2011; Susca et al. 2011; Sfakianaki et al. 2009; Theodosiou 2009).

Changes in insulation and reflective properties influence surface temperatures and radiation conditions, thus affecting thermal comfort (Akbari et al. 2012). In this study, no detectable effects on thermal comfort were modeled by increasing the albedo of the roofs, whether during the night or during the day. This finding is consistent with the work of Emmanuel et al. (2007), who in a similar experiment found no significant changes in PET when the albedo of building facades and roof surfaces was increased by 0.4 or 0.3 , respectively. It is not surprising that the albedo scenario shows no effect on thermal comfort at night, with the lack of incoming solar radiation. On the one hand, the daytime results 
Table 7 Ranking and rating of the 16 adaptation scenarios into four classes based on the average PET reduction potential of the $x$-profile section

\begin{tabular}{llll}
\hline Grade & Ranking points & PET reduction efficiency & Scenario (ranking within grades from high to low) \\
\hline 1 & $24-30$ & Very high & Park WS $3 \mathrm{~m} / \mathrm{s}$, base case WS $3 \mathrm{~m} / \mathrm{s}$, water WS $3 \mathrm{~m} / \mathrm{s}$ \\
2 & $16-23$ & High & Park WS $2 \mathrm{~m} / \mathrm{s}$, base case WS $2 \mathrm{~m} / \mathrm{s}$, water WS $2 \mathrm{~m} / \mathrm{s}$, forest 1 ha \\
3 & $8-15$ & Moderate & Park SM high, park 1 ha, park SM low, roof greening whole area \\
4 & $0-7$ & Low & Park 0.4 ha, water 1 ha, grass 1 ha, albedo, water 0.4 ha \\
\hline
\end{tabular}

may be diminished because changes in the roof level hardly affect pedestrian thermal comfort, as already demonstrated by the roof greening whole area scenario. On the other hand, especially in the daytime situation, there appears to be a leveling effect between the reduction of surface/air temperature and the increase of the radiative temperature by higher albedo and, therefore, reflectance. Considering changes in the albedo of facades, Huttner (2012) even showed a negative effect on pedestrian thermal comfort by increasing albedo.

\section{Assessment of adaptation measures}

In accordance with the purpose of this study, an evaluation of different adaptation scenarios for reducing urban heat stress during the specified hot day situation used for model simulations in this study was performed. Such classification information can serve as a guide to action, especially in urban planning. Mean reductions in PET during both day and night conditions were considered in the classification. Based on the results shown in Tables 5 and 6, score points (ranking from 0 to 15 ) were awarded to the 16 model scenarios according to their nominal position in the ranking of mean PET-reducing potential for both evaluation times, whereby the highest score was given for the highest average PET reduction. The sum of score points of the rank placement of the two evaluation times represents the total score. Thus, the scenarios can be grouped into four efficiency classes with an equidistant interval class of seven score points (Table 7). The maximum reduction of PET in small areas is thus neglected, but this circumstance is accounted for in the assessment of operations in terms of their effectiveness at the community level.

Groups 1 and 2 contain the scenarios with increased initial wind speed. These scenarios show a significant reduction of PET during both day and night, with effects on the entire study area. These scenarios thus differ significantly in their effects from the other adaptation scenarios. The scenario forest 1 ha is included in group 2, which is particularly notable for its high PET reduction during the day. Group 3 contains the park scenarios with differing soil moisture contents and the roof greening whole area scenario. These scenarios still generate a significantly detectable effect for at least at one time situation. Group 4 is made up of the remaining scenarios, namely the water and vegetation scenarios without shading elements or with reduced modified area as well as the albedo scenario. These scenarios either show only a slight local effect on PET or have no detectable effect on thermal comfort (Table 7).

\section{Conclusions}

In this study, the effectiveness of different adaptation measures for the reduction of urban heat stress was investigated by measurements and model simulations in the city of Oberhausen, Germany. Significant differences in the effectiveness of the measures were observed.

The following points summarize the main results:

- An increase in evaporation surface components in an urban neighborhood reduces heat load.

- The effectiveness of individual adaptation measures depends on the kind (vegetation / water / building parameters) and type (e.g., vegetation: grass / park / forest) of the adaptation measure, as well as on meteorological conditions.

- Vegetation areas achieve higher PET reductions than water surfaces due to a combination of evapotranspiration and shading.

- Vegetation areas reach their maximum PET reduction potential only with an adequate water supply. Differences in thermal comfort levels of well-watered and non-irrigated vegetation areas can occur, especially during the daytime.

- Even small changes in area (e.g., park 0.4 ha) can reduce PET and improve thermal comfort. However, of the areas simulated, only the 1-ha water and vegetation scenarios showed an effect on the built-up environment.

- Due to reduced surface roughness, the transport of cooled air by evaporation areas is more likely from and via water surfaces into the build-up surroundings than from vegetated surfaces.

- Wind speed exerts a strong influence on PET. Even a small increase in wind speed leads to a significant decrease in PET. Additionally, long-distance effects on the surrounding built environment are more pronounced with increasing wind speed.

- Ventilation paths are important to improve and maintain the thermal comfort level of an urban neighborhood. 
The preservation and creation of ventilation paths can be recommended for city planning. To optimize adaptation, intraurban parks (minimum size of 1 ha) with adequate water supplies and tall, shady trees should be created. Both shading and evapotranspiration reduce PET. In addition, leaving large distances between trees allows for good ventilation of urban areas. The distances at which parks should be constructed and how many parks are needed for optimal urban human thermal comfort requires further research.

Acknowledgments The dynaklim project, Dynamic adaptation to the effects of climate change in the Emscher-Lippe region (Ruhr area; www.dynaklim.de), on which part of this report is based, was funded by the Federal Ministry of Education and Research (BMBF) under grant number 01LR0804G. The authors are responsible for the content of this publication. The authors would like to thank the Geoinformatics and Environmental Modeling Group of the University of Mainz for providing ENVI-met Version 3.2 and an additional software package for PET calculations. We also thank the EGLV (Emschergenossenschaft/ Lippeverband) for supplying precipitation data. The comments and suggestions of the reviewers are greatly appreciated and helped to improve the quality of the manuscript.

Open Access This article is distributed under the terms of the Creative Commons Attribution License which permits any use, distribution, and reproduction in any medium, provided the original author(s) and the source are credited.

\section{Appendix}

Table 8 Input parameters for model simulations with ENVI-met model version 3.2 and RayMan Pro version 2.1 in Oberhausen, Germany

\begin{tabular}{ll}
\hline Parameter & Value \\
\hline $\begin{array}{l}\text { Position } \\
\text { Geographical position }\end{array}$ & $51^{\circ} 47^{\prime} 0^{\prime \prime} \mathrm{N}, 06^{\circ} 85^{\prime} 00^{\prime \prime} \mathrm{E}$ \\
Model dimensions & \\
Number of grid cells $(x, y, z)$ & $230,230,30$ \\
Size of grid cells $(x, y, z)$ & $2 \mathrm{~m}, 2 \mathrm{~m}$, increasing \\
& with height \\
Size of model area $(x, y, z)$ & $460 \mathrm{~m}, 460 \mathrm{~m}, 128.4 \mathrm{~m}$ \\
Nesting grids $(x, y, z)$ & $9,9,9$ \\
Model rotation out of grid north & $5.5^{\circ}$ \\
Meteorological boundary conditions & \\
Total simulation time & $44 \mathrm{~h}$ \\
Start simulation at day & $10 \mathrm{July} 2010$ \\
Start simulation at time (h/min/s) & $04: 00: 00$ \\
Wind speed at $10 \mathrm{~m}$ a.g.l. & Initial: $1 \mathrm{~m} / \mathrm{s}$, modified: \\
& $2 \mathrm{~m} / \mathrm{s}, 3 \mathrm{~m} / \mathrm{s}$ \\
Wind direction & $75^{\circ}$ \\
Roughness length, $z 0$ & 1.0 \\
Minimum air temperature $(4 \mathrm{CET})$ & $22.7^{\circ} \mathrm{C}$ \\
Maximum air temperature $(16 \mathrm{CET})$ & $35.2{ }^{\circ} \mathrm{C}$ \\
Maximum relative & $72.2 \%$ \\
humidity $(4 \mathrm{CET})$ &
\end{tabular}

Table 8 (continued)

\begin{tabular}{ll}
\hline Parameter & Value \\
\hline $\begin{array}{l}\text { Minimum relative } \\
\text { humidity (16 CET) }\end{array}$ & $30.8 \%$ \\
Solar access & Default: 1.0 \\
Sky cover & Default: no clouds \\
Soil parameter & \\
Soil type & Sandy soil \\
Initial temperature upper layer $(0-20 \mathrm{~cm})$ & $304.5 \mathrm{~K}$ \\
Initial temperature middle layer $(20-50 \mathrm{~cm})$ & $303.0 \mathrm{~K}$ \\
Initial temperature deep layer $(>50 \mathrm{~cm})$ & $299.6 \mathrm{~K}$ \\
Soil moisture content upper & Initial: $40 \%$, low, \\
layer (0-20 cm) & $20 \%$, high, $60 \%$ \\
Soil moisture content middle & Initial: $50 \%$, low, \\
layer (20-50 cm) & $30 \%$, high, $60 \%$ \\
Soil moisture deep layer $(>50 \mathrm{~cm})$ & Initial: $60 \%$, low, \\
& $30 \%$, high, $70 \%$ \\
Building parameter & \\
Interior temperature & $296 \mathrm{~K}$ \\
Heat transmission & Default: $1.94 \mathrm{~W} /\left(\mathrm{m}^{2} \mathrm{~K}\right)$ \\
coefficient walls & Default: 1.0 \\
Heat transmission & Default: 0.3 \\
coefficient roofs & Default: $6 \mathrm{~W} /\left(\mathrm{m}^{2} \mathrm{~K}\right)$ \\
Albedo walls & 0.2 \\
Albedo roofs & Initial: 0.3, modified, 0.65 \\
Thermal comfort (PET) & \\
Work metabolism & $30 \mathrm{~W}$ \\
Age & Male \\
Sex & 0.9 \\
Static clothing insulation $(\mathrm{clo})$ & \\
Additional parameters of RayMan & \\
Meteorological parameters & \\
Bowen ratio & \\
Albedo & \\
\hline
\end{tabular}

*no height correction of the measurement data took place, because model simulations showed that changes of the wind speed data between measuring height $(3.8 \mathrm{~m})$ and input height $(1.1 \mathrm{~m})$ only occurred in the second decimal place

\section{References}

Akbari H, Matthews HD, Seto D (2012) The long-term effect of increasing the albedo of urban areas. Environ Res Lett. doi:10.1088/1748-9326/7/2/024004

Ali-Toudert F (2005) Dependence of outdoor thermal comfort on street design in hot and dry climate. Ber des Meteorol Inst der Universität Freiburg 15. Freiburg

Ali-Toudert F, Mayer H (2005) Thermal comfort in urban streets with trees under hot summer conditions. In: Proc. 22th Int. Conf. Passive Low Energy Architect, Beirut, Lebanon 13-16: 699704. (PLEA 2005)

Ali-Toudert F, Mayer H (2007) Effects of asymmetry, galleries, overhanging façades and vegetation on thermal comfort in urban street canyons. Solar Energy 81:742-754 
Allen WL (2012) Advancing green infrastructure at all scales: from landscape to site. Environ Pract 14:17-25. doi:10.1017/ S1466046611000469

Barlag A-B, Kuttler W (1990/91) The significance of country breezes for urban planning. energy and build 15-16: 291-297

Bezirksregierung Köln (2010) Digitales Oberflächenmodell (Digital surface model). (DVD)

Bongardt B (2006) Stadtklimatische Bedeutung kleiner Parkanlagendargestellt am Beispiel des Dortmunder Westparks (Influence of small park areas on the urban climate - the example of Westpark in Dortmund, Germany). Essener Oekol Schr 24. Westarp, Hohenwarsleben

Bruse M (2000) Anwendung von mikroskaligen Simulationsmodellen in der Stadtplanung (Application of micro-scale numerical models in urban planning. In: Bernhard L, Küger T (eds) Simulation raumbezogener Prozesse: Methoden und Anwendung IfGIprints 9. Inst. für, Geoinformatik

Bruse M (2010) ENVI-met version 3.2. and calcPET tool. Personal communication

Bruse M, Fleer H (1998) Simulating surface-plant-air interactions inside urban environments with a three dimensional numerical model. Environ Modell and Softw 13:373-384

Carnielo E, Zinzi M (2013) Optical and thermal characterisation of cool asphalts to mitigate urban temperatures and building cooling demand. Build Environ 60:56-65

Charalampopoulos I, Tsiros I, Chronopoulou-Sereli A, Matzarakis A (2012) Analysis of thermal bioclimate in various urban configurations in Athens. Greece Urban Ecosyst. doi:10.1007/s11252012-0252-5

Chow WTL, Pope RL, Martin CA, Brazel AJ (2011) Observing and modeling the nocturnal park cool island of an arid city: horizontal and vertical impacts. Theor Appl Climatol 103:197-211

Cohen P, Potchter O, Matzarakis A (2012) Daily and seasonal climatic conditions of green urban open spaces in the Mediterranean climate and their impact on human comfort. Build Environ 51:285-295. doi:10.1016/j.buildenv.2011.11.020

DWD - Deutscher Wetterdienst (ed) (2011) Long-term temperature averages (1961-1990) from Duisburg-Laar. http://www.dwd.de. Accessed 14 June 2011.

EGLV (Emschergenossenschaft/Lippeverband) (2011) Precipitation data of the Station Oberhausen-Buschhausen for climate normal period 1961-1990. Personal communication

Emmanuel R, Rosenlund H, Johansson E (2007) Urban shading - a design option for the tropics? A case study in Colombo, Sri Lanka. Int J Climatol 27:1995-2004. doi:10.1002/joc.1609

Georgie JN, Dimitriou D (2010) The contribution of urban green spaces to the improvement of environment in cities: case study of Chania, Greece. Build Environ 45(6):1401-1414

Gill SE, Handley JF, Ennos AR, Pauleit S (2007) Adapting cities for climate change: the role of the green infrastructure. Built Environ $33: 115-133$

Goldbach A (2012) Turbulenter Energieaustausch über unterschiedlichen Flächennutzungsstrukturen in der Stadt Oberhausen. (Turbulent energy exchange for different land use patterns in the city of Oberhausen; in German). Essener Oekol Schr 32. Westarp, Hohenwarsleben

Goldbach A, Kuttler W (2012) Quantification of turbulent heat fluxes for adaptation strategies within urban planning. Int J Climatol. doi:10.1002/joc. 3437

Gross G (2012) Numerical simulation of greening effects for idealized roofs with regional climate forcing. Meteorol Z 21:173-181

Gulyás A, Unger J, Matzarakis A (2006) Assessment of the microclimatic and human comfort conditions in a complex urban environment: modelling and measurements. Build Environ 41:17131722. doi:10.1016/j.buildenv.2005.07.001
Höppe P (1999) The physiological equivalent temperature-a universal index for the biometeorological assessment of the thermal environment. Int Journal of Biometeorol 43:71-75. doi:10.1007/ s004840050118

Huttner S (2012) Further development and application of the 3D microclimate simulation ENVI-met. Dissertation, University of Mainz. ubm.opus.hbz-nrw.de/volltexte/2012/3112/. Accessed 13 August 2012

Huttner S, Bruse M, Dostal P (2009) Using ENVI-met to simulate the impact of global warming on the microclimate in central European cities. In: Mayer H, Matzarakis A (eds). 5th JapaneseGerman Meeting on Urban Climatology, October 2008. Ber des Meteorol Inst der Universität Freiburg 18, pp 307-312

IPCC-Intergovernmental Panel on Climate Change (2007) Climate change 2007: synthesis report. Contribution of Working Groups I, II and III to the Fourth Assessment Report of the Intergovernmental Panel on Climate Change [Core Writing Team, Pachauri RK, Reisinger A (eds)]. IPCC, Geneva, Switzerland

IT.NRW - Information und Technik Nordrhein-Westfalen (2011a) Amtliche Bevölkerungszahlen (Government population statistics). http:// www.it.nrw.de/statistik/a/daten/amtlichebevoelkerungszahlen/ index.html. Accessed 25 January 2012

IT.NRW-Information und Technik Nordrhein-Westfalen (2011b) Geoinformationszentrum (Geo-information center). http:// www.gis4.nrw.de/DienstelisteInternet. Accessed 31 May 2011

Jendritzky G, de Dear R, Havenith G (2012) UTCI-why another thermal index? Int J Biometeorol 56:421-428. doi:10.1007/ s00484-011-0513-7

Kántor N, Unger J (2010) Benefits and opportunities of adopting GIS in thermal comfort studies in resting places: an urban park as an example. Landsc and Urban Plan 98:36-46

Krüger EL, Pearlmutter D (2008) The effect of urban evaporation on building energy demand in an arid environment. Energy and Build 40:2090-2098. doi:10.1016/j.enbuild.2008.06.002

Kuttler W (2011) Climate change in urban areas, part 2, measures. Environ Sci Eur (ESEU) 23:21

Kuttler W (2012) Climate change on the urban scale - effects and countermeasures in Central Europe. In: Chhetri N (ed) Human and Social Dimensions. In Tech, Croatia, pp 105-142. doi: $10.5772 / 50867$

Kuttler W, Müller N, Dütemeyer D, Barlag A-B (2012a) Prognose- und Diagnoseanalysen zur Verbesserung des Stadtklimas. dynaklim-Publ 25. http://dynaklim.ahu.de/dynaklim/index/wissensmanagement/ publikationen/dynaklim_Publikationen-2012.html. Accessed 07 May 2012

Kuttler W, Püllen H, Dütemeyer D, Barlag A-B (2012b): Unterirdische Wärmeinsel in Oberhausen; Untersuchung subterraner Wärmeund Energieflüsse in verschiedenen Klimatopen. dynaklim-Publ 23. http://dynaklim.ahu.de/dynaklim/index/wissensmanagement/ publikationen/dynaklim_Publikationen-2012.html. Accessed 07 May 2012

Laaidi K, Zeghnoun A, Dousset B, Bretin P, Vandentorren S, Giraudet E, Beaudeau P (2012) The impact of heat islands on mortality in Paris during the August 2003 heat wave. Environ Health Perspect 120:254-259

LANUV-Landesamt für Natur, Umwelt und Verbraucherschutz Nordrhein-Westfalen (ed) (nd) Klimaatlas NRW (Climatic atlas of North Rhine-Westphalia). Datenquelle Deutscher Wetterdienst (Windrosen: Düsseldorf 1981-2010, Essen 2001-2010). http://www.klimaatlas.nrw.de. Accessed 18 April 2012

Liang H-H, Huang K-T (2011) Study on rooftop outdoor thermal environment and slab insulation performance of grass planted roof. Int J of the Phys Sci 6:65-73 
Lin B, Li X, Zhu Y, Qin Y (2008) Numerical simulation studies of the different vegetation patterns' effects on outdoor pedestrian thermal comfort. J Wind Eng Ind Aerodyn 96:17071718

Lin T-P, Matzarakis A, Hwang R-L (2010) Shading effect on long-term outdoor thermal comfort. Build Environ 45:213-221. doi:10.1016/j.buildenv.2009.06.002

Lopes A, Lopes S, Matzarakis M, Alcoforado MJ (2011) The influence of the summer sea breeze on thermal comfort in Funchal (Madeira). A contribution to tourism and urban planning. Meteorol Z 20:553-564. doi:10.1127/0941-2948/2011/0248

Mahmoud AHA (2011) Analysis of the microclimatic and human comfort conditions in an urban park in hot and arid regions. Build Environ 46:2641-2656. doi:10.1016/j.buildenv.2011.06.025

Matzarakis A (2010) RayMan. http://www.urbanclimate.net/rayman. Accessed 31 October 2011

Matzarakis A, Endler C (2010) Climate change and thermal bioclimate in cities: impacts and options for adaptation in Freiburg, Germany. Int J Biometeorol 54:479-483

Matzarakis A, Mayer H (1996) Another kind of environmental stress: thermal stress. Newsletter of WHO Colloborating Centre for Air Quality Management and Air Pollution Control 18:7-10

Matzarakis A, Mayer H, Iziomon MG (1999) Applications of a universal thermal index: physiological equivalent temperature. Int $\mathrm{J}$ Biometeorol 43:76-84

Matzarakis A, Rutz F, Mayer H (2007) Modelling radiation fluxes in simple and complex environments-application of RayMan model. Int J Biometeorol 51:323-334. doi:10.1007/s00484006-0061-8

Matzarakis A, Rutz F, Mayer H (2010) Modelling radiation fluxes in simple and complex environments: basics of the RayMan model. Int J Biometeorol 54:131-139. doi:10.1007/s00484009-0261-0

Mayer H (2006) Indizes zur human-biometeorologischen Bewertung der thermischen und lufthygienischen Komponente des Klimas. Gefahrstoffe - Reinhalt der Luft 66:165-174

Mayer H, Höppe P (1987) Thermal comfort of man in different urban environments. Theor Appl Climatol 38:43-49

Mayer H, Kuppe S, Holst J, Imbery F, Matzarakis A (2009) Human thermal comfort below the canopy of street trees on a typical Central European summer day. In: Mayer H, Matzarakis A (eds). 5th Japanese-German Meeting on Urban Climatology, October 2008. Ber des Meteorol Inst der Universität Freiburg 18 , pp 211-219

MUNLV NRW-Ministerium für Klimaschutz, Umwelt, Landwirtschaft, Natur- und Verbraucherschutz des Landes Nordrhein-Westfalen (ed) (2010) Handbuch Stadtklima-Maßnahmen und Handlungskonzepte für Städte und Ballungsräume zur Anpassung an den Klimawandel (Urban climate guide - climate change adaptation measures and strategies for cities.) Langfassung. http:// www.umwelt.nrw.de/klima/klimawandel/anpassungspolitik/ projekte/staedte und ballungsraeume/projektseite_01/index.php. Accessed 11 April 2011

Murakawa S, Sekine T, Narita K-I (1990/91) Study of the Effects of a river on the thermal environment in an urban Area. Energy and Build 15-16: 993-1001

Ng E, Chen L, Wang Y, Yuan C (2012) A study on the cooling effects of greening in a high-density city: An experience from Hong Kong. Build Environ 47:256-271. doi:10.1016/j. buildenv. 2011.07.014

Oliveira S, Andrade H, Vaz T (2011) The cooling effect of green spaces as a contribution to the mitigation of urban heat: a case study in Lisbon. Build Environ 46:2186-2194

Potchter O, Cohen P, Bitan A (2006) Climatic behavior of various urban parks during hot and humid summer in the Mediterranean city of Tel Aviv, Israel. Int J Climatol 26:1695-1711. doi:10.1002/ joc. 1330

Püllen H (2010) Soil temperature data for 10 July 2010 at compact midrise station 1 in Oberhausen. Persponal communication

RVR-Regionalverband Ruhr (2011) Metropoleruhr.de-Bevölkerung (Population). http://www.metropoleruhr.de/regionalverband-ruhr/ analysen-statistik/regionalstatistik/bevoelkerung/ entwicklung.html. Accessed 09 May 2012

Saaroni H, Ziv B (2003) The impact of small lake on heat stress in a Mediterranean urban park: the case of Tel Aviv, Israel. Int J Biometeorol 47:156-165. doi:10.1007/s00484-003-0161-7

Sfakianaki A, Pagalou E, Pavlou K, Santamouris M, Assimakopoulos MN (2009) Theoretical and experimental analysis of the thermal behavior of a green roof system installed in two residential buildings in Athens, Greece. Int $J$ of Energy Res 33:1059-1069

Shashua-Bar L, Pearlmutter D, Erell E (2009) The cooling efficiency of urban landscape strategies in a hot dry climate. Landsc and Urban Plan 92:179-186

Shashua-Bar L, Pearlmutter D, Erell E (2011) The influence of trees and grass on outdoor thermal comfort in a hot-arid environment. Int J Climatol 31:1498-1506. doi:10.1002/joc.2177

Shashua-Bar L, Tsiros IX, Hoffman M (2012) Passive cooling design options to ameliorate thermal comfort in urban streets of a Mediterranean climate (Athens) under hot summer conditions. Build Environ 57:110-119

Spronken-Smith RA, Oke TR (1998) The thermal regime of urban parks in two cities with different summer climates. Int J Remote Sens 19:2085-2104. doi:10.1080/014311698214884

Spronken-Smith RA, Oke TR (1999) Scale modelling of nocturnal cooling in urban parks. Bound-Layer Meteorol 93:287-312. doi:10.1023/A:1002001408973

Stadt Oberhausen (2012) Realnutzungskartierung 2009 (Land use mapping 2009). Stadt Oberhausen Fachbereich 2-2-10

Stewart ID (2011) Redefining the urban heat island. Dissertation, University of British Columbia. https://circle.ubc.ca/handle/ 2429/38069. Accessed 23 February 2012

Streiling S, Matzarakis A (2003) Influence of single and small clusters of trees on the bioclimate of a city: a case study. J of Arboriculture 29(6):309-315

Sun R, Chen L (2012) How can urban water bodies be designed for climate adaptation? Landsc and Urban Plan 105:27-33

Susca T, Gaffin SR, Dell'Osso GR (2011) Positive effects of vegetation: urban heat island and green roofs. Environ Pollut 159:21192126

Svensson MK, Thorsson S, Lindqvist S (2003) A geographical information system model for creating bioclimatic maps-examples from a high, mid-latitude city. Int J Biometeorol 47:102-112. doi:10.1007/s00484-002-0150-2

Theodosiou T (2009) Green roofs in buildings: thermal and environmental behaviour. Adv in Build Energy Res 3:271-288. doi:10.3763/aber.2009.0311

Thorsson S, Lindberg F, Eliasson I, Holmer B (2007) Different methods for estimating the mean radiant temperature in an outdoor urban setting. Int J Climatol 27:1983-1993. doi:10.1002/joc.1537

Thorsson S, Lindberg F, Björklund J, Holmer B, Rayner D (2011) Potential changes in outdoor thermal comfort conditions in Gothenburg, Sweden due to climate change: the influence of urban geometry. Int J Climatol 31:324-335

Xu J, Wie Q, Huang X, Zhu X, Li G (2010) Evaluation of human thermal comfort near urban waterbody during summer. Build Environ 45:1072-1080. doi:10.1016/j.buildenv.2009.10.025

Yang F, Lau SSY, Qian F (2011) Thermal comfort effects of urban design strategies in high-rise urban environments in a sub-tropical climate. Archit Sci Rev 54(4):285-304 